\title{
An unusual presentation of girl with down syndrome: Van-Wyk Grumbach syndrome
}

\author{
Han Hyuk Lim*, Hong Ryang Kil, Jae Young Kim \\ From 7th APPES Biennial Scientific Meeting \\ Nusa Dua, Bali. 14-17 November 2012
}

Van Wyk-Grumbach syndrome is a rare disease characterized by precocious puberty associated with prolonged hypothyroidism and multicystic enlarged ovaries. A9 year-old girl with Down syndrome visited our hospital for early menarche. At birth, she showed subclinical hypothyroidism $(11.8 \mathrm{mg} / \mathrm{dL}$ of thyroxine (T4) and $6.05 \mathrm{mIU} / \mathrm{mL}$ of thyroid stimulating hormone (TSH)), but she had not been followed up in our clinic. On physical examination, pubertal Tanner stage was breast II and pubic hair I. Laboratory findings were as follows; $0.30 \mathrm{ng} /$ $\mathrm{dL}$ of free T4, $81.30 \mathrm{uIU} / \mathrm{mL}$ of TSH, $0.1 \mathrm{IU} / \mathrm{L}$ of luteinizing hormone, and $6.35 \mathrm{IU} / \mathrm{L}$ of follicle-stimulating hormone. Her bone age was 6 years. Her pelvic sonogram revealed multiple cysts in both enlarged ovaries. She was diagnosed with Van Wyk-Grumbach syndrome. Levothyroxine treatment at a dose of $0.05 \mathrm{mg} /$ day was started. Regression of breast development was obtained after 2 months and her vaginal bleeding did not recur.

Submit your next manuscript to BioMed Central and take full advantage of:

- Convenient online submission

- Thorough peer review

- No space constraints or color figure charges

- Immediate publication on acceptance

- Inclusion in PubMed, CAS, Scopus and Google Scholar

- Research which is freely available for redistribution
(C) $2013 \mathrm{Lim}$ et al; licensee BioMed Central Ltd. This is an Open Access article distributed under the terms of the Creative Commons Attribution License (http://creativecommons.org/licenses/by/2.0), which permits unrestricted use, distribution, and reproduction in any medium, provided the original work is properly cited. 